\title{
David Oliver: Taking carers for granted
}

\author{
David Oliver consultant in geriatrics and acute general medicine
}

Berkshire

David Mowat, the health minister, raised a few eyebrows earlier this year when he said that people had the same duty to look after their ageing parents as they did to look after their children. ${ }^{1}$

Mowat, who was giving evidence to the communities and local government select committee, acknowledged the current problems in the care system and its future sustainability. He then added, "No one ever questions that we look after our children-that is obvious. No one says that is a caring responsibility, it is what we do.

"Some of that logic and some of the way we think about that . .. will have to impinge on the way that we think about caring for our parents. Because it is a responsibility in terms of our life cycle which is similar."

Mowat isn't the first politician or commentator to make this kind of plea. The health secretary, Jeremy Hunt, said in 2013 that we should "adopt the Asian culture of caring for the elderly." ${ }^{2}$ Yet, even in countries such as China and Japan, urbanisation, falling birth rates, increasing longevity, changing gender roles, and working lives mean that Hunt's stereotype decreasingly holds true. ${ }^{34}$

Carers are often spouses rather than offspring. Around two million are over 65 , and half a million are over 80

The Organisation for Economic Co-operation and Development's health report shows that an average of $17 \%$ of OECD citizens over 50 are informal family carers-most, at least daily. ${ }^{5}$ Many combine this with parenting and grandparenting.

Closer to home, the House of Lords committee on ageing and public services concluded that around 6.4 million people care for someone over 65-twice the number working in health and care services. "The bulk of care is and always has been provided by families," the report stated. ${ }^{6}$

The Lords heard that the intensity of the caring burden had grown, as the number of people providing care for more than 50 hours a week has doubled in a decade. At current demographic projections the number of older people needing such informal care will soon outstrip the system's ability to meet that demand.

Many people age without children. Some outlive theirs. Others have none nearby. Others don't want to be a burden.

Carers are often spouses rather than offspring. ${ }^{7}$ Around two million are over 65 , and half a million are over $80 .{ }^{8}$ Many are in poor physical or mental health, either impeding their caring role or resulting from it.

Meanwhile, less than 5\% of UK carers receive statutory support. ${ }^{8}$ We have lost capacity in long term residential and home care since 2010. ${ }^{9}$ Unless you have the money to pay for care, you won't get near the threshold for a care home or home care without very high needs. Yet carers contribute an estimated $£ 100$ bn to the economy through unpaid work, often to the detriment of their own jobs. ${ }^{7}$

When help arrives, ${ }^{10}$ even through crisis admissions to hospital, ${ }^{11}$ carers are often emotionally and physically exhausted and grateful that, at last, something's on offer. ${ }^{11}$

Unless you've been a carer or worked in roles supporting carers, you'll have little idea of the work they do. Talk is much cheaper than funding the care system properly.

\section{Competing interests: See www.bmj.com/about-bmj/freelance- contributors/david-oliver.}

Provenance and peer review: Commissioned; not externally peer reviewed.

Asthana A. Take care of your elderly mothers and fathers, says Tory minister. Guardian 31 Jan 2017. https://www.theguardian.com/society/2017/jan/31/take-care-of-your-elderlymothers-and-fathers-says-tory-minister.

2 Hunt J. UK should adopt Asian culture of caring for the elderly. Guardian 18 Oct 2013. https://www.theguardian.com/politics/2013/oct/18/jeremy-hunt-uk-families-asia-elderly.

Oi M. Who will look after Japan's elderly? BBC News 16 Mar 2015. www.bbc.co.uk/news/ world-asia-31901943.

4 Xie C. The graying of China and Japan: a comparative study of elder care attitudes and policy implications. Princeton University thesis. 2016. http://dataspace.princeton.edu/jspui/ handle/88435/dsp01gq67jt649.

5 Organisation for Economic Co-operation and Development. Health at a glance 2015-OECD indicators. 4 Nov 2015. www.oecd.org/health/health-systems/health-at-aglance-19991312.htm.

6 House of Lords Select Committee on Public Service and Demographic Change. Ready for ageing? Annex 15: informal care. 5 Mar 2013. https://www.publications.parliament.uk/ pa/ld201213/ldselect/ldpublic/140/14018.htm.

7 Carers Trust. Key facts about carers and the people they care for. https://carers.org/keyfacts-about-carers-and-people-they-care. 
8 Age UK. Briefing: health and care of older people in England 2017. Feb 2017. www.ageuk. org.uk/Documents/EN-GB/For-professionals/Research/The Health and Care of Older People in England 2016.pdf?dtrk=true.

9 Humphries R, Hall P, Charles A, Thorlby R, Holder H; King's Fund, Nuffield Trust. Social care for older people: home truths. 15 Sept 2016. https://www.kingsfund.org.uk/ publications/social-care-older-people.

10 Richmond Group of Charities. Real lives: listening to the voices of people who use social care. Sept 2016. https://richmondgroupofcharities.org.uk/sites/default/files/lr_5285_the_ richmond group_social_care_real_lives_report.pdf.
11 Glasby J, Littlechild R, Le Mesurier N, et al; University of Birmingham School of Social Policy, National Institute for Health Research. Who knows best? Older people's contribution to understanding and preventing avoidable hospital admissions. 2016. www.birmingham. ac.uk/Documents/college-social-sciences/social-policy/HSMC/publications/2016/whoknows-best.pdf.

Published by the BMJ Publishing Group Limited. For permission to use (where not already granted under a licence) please go to http://group.bmj.com/group/rights-licensing/ permissions 